\title{
JOB SATISFACTION AMONG SOUTH AFRICAN AIRCRAFT PILOTS
}

\author{
C HOOLE \\ L P VERMEULEN \\ Department of Human Resources Management \\ University of Pretoria
}

\begin{abstract}
The importance of job satisfaction to human beings is a widely studied phenomenon, due to the assumption that job satisfaction is a major contributor to the well-being of employees and to several organisational outcomes. Most of these studies have focused on the influence of organisational variables on job satisfaction. Few studies have investigated the relationship between pilot-related factors and the job satisfaction levels of aviators. In a study of 704 South African pilots, significant differences were found in job satisfaction levels with regard to the nature of a pilot's flying duty, area(s) of operation, type(s) of licence and level of command.
\end{abstract}

\section{OPSOMMING}

Werkstevredenheid en die belangrikheid daarvan vir die mens is ' $n$ onderwerp waaroor navorsing dikwels gedoen word. Die rede hiervoor is die aanname dat werkstevredenheid ' $n$ belangrike bydraende faktor is tot werknemerswelsyn en verskeie organisatoriese uitkomste. Die meeste van hierdie studies het gekonsentreer op die invloed van organisatoriese veranderlikes op werkstevredenheid. Min navorsing is egter gedoen oor die verband tussen vliegverwante veranderlikes en die vlakke van werkstevredenheid van vlieëniers. In 'n studie van 704 Suid-Afrikaanse vlieëniers is beduidende verskille gevind tussen die werkstevredenheidsvlakke van vlieëniers met betrekking tot die aard van vlieëniers se vliegtaak, area(s) van werksaamheid, soort(e) lisensie(s) en vlak van bevelvoering.

In aviation, safety is paramount. The human factor is widely recognised to be critical to aviation safety and effectiveness. Numerous studies have indicated that the human factor is absolutely vital in maintaining or improving safety. These realities suggest that there is a need for consistent, long-term support for research, development, analysis and application of information related to human performance throughout the aviation system (McDonald, Johnston \& Fuller, 1995).

Because this need was recognised, a United States National Plan for Aviation Human Factors was developed and published in 1990. The strategic portion of the plan calls for research which leads to enhancements in (a) human centred design of controls, displays and advanced systems; (b) selection and training; (c) information transfer; (d) personal safety, well-being and survival and; (e) the measurement of performance and an understanding of variables that affect performance (FAA, 1990; Dismukes, 1994). This article supports objective (e) of this scientific programme in aviation human factor research.

Since job satisfaction can be regarded as an important contributor to various aspects of work performance, an investigation of the level of job satisfaction of South African aircraft pilots and the variables that affect it can make a valuable scientific contribution.

The importance of job satisfaction to human beings is a phenomenon that has been widely studied. The popularity of this field of study can be attributed to the relevance of job satisfaction to the physical and mental well-being of employees. Most of these studies focus on the humanitarian value of job satisfaction. They are based on the implicit assumption that job satisfaction (or lack thereof) is a major contributor to productivity, absenteeism, turnover, in-role job performance and extra-role behaviour and role stress, as well as the belief that management is able to influence the primary antecedents of job attitudes. Job satisfaction can be described as a person's affective attachment to his/her job, either in its entirety (global satisfaction) or with regard to particular aspects, seen as facet job satisfaction (Tett \& Meyer, 1993).

Several studies have explored the relationship between job satisfaction and variables such as age, gender, rank, length of service, job facets, job levels, intention to quit and commitment

Requests for copies should be addressed to: C Hoole, Department of Human

Resource Management, University of Pretoria, Pretoria, 0002
(Oshagbemi, 1999; Khaleque \& Rahman, 1987; Robie, Ryan, Schmieder, Parra \& Smith, 1998; Tett \& Meyer, 1993). However, none of these studies has investigated the relationship between pilot-related factors and the job satisfaction levels of aviators. There are numerous publications (Wiener \& Nagel, 1988; Besco, 1989; Hawkins, 1993; Johnston, Fuller \& McDonald, 1995; Fuller, Johnston \& McDonald, 1995; O'Hare \& Roscoe, 1994; Hayward \& Lowe, 1996, 2000; Orlady \& Orlady, 1999; Lowe \& Hayward, 2000) that refer to research on the influence of specific factors (for example, automation, work overload, jet lag, irregular working hours, cockpit design and layout) on job performance and pilot error in flight operations. Very few of these publications refer to working conditions or their specific contribution to the intrinsic job satisfaction of pilots.

The broad aim of the sudy was to rectify these omissions. Hence, the objectives of the study were:

- to ascertain whether the Job Satisfaction Scale developed by Brayfield and Rothe can be used for pilots in the South African context; and

- to determine whether pilots' levels of job satisfaction differ as a function of their area(s) of operation, the nature of their flying duty, the type of licence they have and their level of command.

The following hypotheses were developed with regard to the second objective of the study:

H1: There is a statistically significant difference between the mean job satisfaction scores of groups of pilots operating in different areas.

$\mathrm{H} 2$ : There is a statistically significant difference between the mean job satisfaction scores of groups of pilots who perform different flying duties.

H3: There is a statistically significant difference between the mean job satisfaction scores of pilots licenced in different categories.

H4: There is a statistically significant difference between the mean job satisfaction scores of pilots in different levels of command.

\section{METHOD}

\section{Measuring instrument}

The study can be seen as exploratory in nature, investigating pilot-related factors that may influence the levels of job satisfaction of South African aircraft pilots. 
The first part of the survey focused on the evaluation of items measuring job satisfaction.

The instrument used in the survey was the Job Satisfaction Scale (JSS) developed by Brayfield and Rothe (1951). The scale consists of 18 items with five-point agree-disagree responses. Other items also included in the survey consisted of biographical questions and some crew resource management questions.

The instrument was developed to measure job satisfaction in a wide variety of jobs. A mean score of 63,8 (SD 9,4) and an internal consistency of 0,87 were reported. Studies using the Brayfield-Rothe scale reported reliability scores of 0,87 (Brayfield \& Rothe, 1951), 0,90 and 0,78 (Brayfield, Wells \& Strate, 1957), 0,99 (Stinson \& Johnson, 1977), 0,9 (Carson, Carson, Roe, Birkenmeyer \& Phillips, 1999). At least one study also used the Brayfield-Rothe scale to focus on a narrower aspect of job satisfaction, namely satisfaction with the work itself (Stone, Mowday \& Porter, 1977). They found that this type of satisfaction correlated 0,43 with job scope (perceived variety, autonomy, task identity and feedback). The Brayfield-Rothe instrument was also used in several other studies (Martin, 1979; Orpen, 1978; O'Reilly \& Caldwell, 1979; Khaleque \& Rahman, 1987; Iverson, 1999; Carson et al., 1999).

\section{Procedure}

Questionnaires were distributed in two phases. The Air Force Headquarters distributed 250 questionnaires to the various pilot divisions. In the second phase, the South African Civil Aviation Authority distributed 7929 questionnaires via the Aeronautical Information circular (NOTAM) to all licenced pilots in the following categories: 4625 private pilots, 1512 airline transport pilots, 1468 commercial pilots, 218 helicopter commercial pilots and 106 helicopter airline transport pilots. Altogether, a total of 8179 questionnaires were distributed. A total of 704 questionnaires were returned, a return rate of $8,60 \%$.

The descriptions of the respondents in terms of biographic characteristics, areas of flight operation and the nature of these pilots' aviation duty are presented in Tables 1 and 2 .

TABLE 1

BIOGRAPHIC CHARACTERISTICS OF RESPONDENTS

\begin{tabular}{llll}
\hline Biographic Variables & & & \\
\hline Gender & Male & $\mathrm{n}=672$ & 704 \\
& Female & $\mathrm{n}=32$ & \\
\cline { 2 - 4 } Educational qualifications & Degree & $\mathrm{n}=152$ & 704 \\
& Diploma & $\mathrm{n}=133$ & \\
& Other & $\mathrm{n}=419$ & \\
\hline Age & Mean 35,6 & SD 10,68 & \\
Total flying hours & Mean 3877,48 & SD 4274,04 & \\
\hline
\end{tabular}

\section{Statistical analysis}

Parametric statistics were used to determine associative and comparative trends in the data. An interval scale was used as the level of measurement for the dependent variable (job satisfaction). To examine the internal structure and factor validity of the Job Satisfaction Scale, a principal factor analysis and confirmatory factor analysis were used. Principal factor analysis was used because this is the procedure recommended when an attempt is made to determine the number and content of factors measured by an instrument (Hatcher, 1994). The internal reliability of the Job Satisfaction Scale was assessed by calculating the Cronbach alpha coefficient. One-way analysis of variance (ANOVA) was used to compare the job satisfaction levels of three or more independent groups. To indicate which group or groups differ significantly, the post hoc test of Scheffe was applied. The BMDP4M and SAS-Proc Calis computer programmes were used to perform a factor analysis of the items. The rest of the statistical analyses were done by means of the Statistical Programme for Social Sciences (SPSS for Windows 9.0).

TABLE 2

MAIN AREAS OF OPERATION AND NATURE OF FLYING DUTY

\begin{tabular}{lcc}
\hline Areas of Operation & $\mathrm{N}$ & $\%$ \\
\hline National airline & 188 & 26,2 \\
Charter & 88 & 12,5 \\
Corporate & 39 & 5,5 \\
Freight & 8 & 1,2 \\
Military & 219 & 31,2 \\
Other & 162 & 23,4 \\
\hline Total & 704 & 100 \\
\hline Nature of Flying Duty & & \\
\hline Passenger transportation & 377 & 53,5 \\
Freight & 14 & 2,0 \\
Agricultural (crop dusting, etc.) & 10 & 1,4 \\
Industrial/construction & 10 & 1,4 \\
Aerial surveying (photography, mapping, etc.) & 11 & 1,6 \\
Aerial patrol & 31 & 4,4 \\
Pilot training/Flight instruction & 80 & 11,3 \\
Sales and demonstration & 2 & 0,3 \\
Personal flying (sport, recreation) & 61 & 8,8 \\
Student pilots & 50 & 7,1 \\
Other & 58 & 8,2 \\
\hline Total & 704 & 100 \\
\hline & & \\
\hline
\end{tabular}

\section{RESULTS}

\section{Factor analyses}

The responses of 704 pilots on the Job Satisfaction Scale were subjected to the Principal Factors Analysis using the BMDP4M programme. The first round of the analyses indicated a threefactor solution, where three roots had eigenvalues greater than one. The eigenvalues of the inter-correlation matrix are set out in Table 3.

TABLE 3

EIGENVALUES OF THE INTER-CORRELATION MATRIX

\begin{tabular}{cc}
\hline Root & Eigenvalue \\
\hline 1 & 6,7589 \\
2 & 1,2305 \\
3 & 1,0441 \\
4 & 0,9546 \\
5 & 0,8942 \\
6 & 0,8297 \\
7 & 0,7797 \\
8 & 0,7127 \\
9 & 0,6895 \\
10 & 0,6675 \\
11 & 0,5553 \\
12 & 0,5256 \\
13 & 0,4949 \\
14 & 0,4390 \\
15 & 0,4301 \\
16 & 0,3716 \\
17 & 0,3422 \\
18 & 0,3068 \\
\hline
\end{tabular}


The difference between the three eigenvalues already suggested that there was actually only one significant factor. A two-factor solution was requested and the items were subjected to further exploratory factor analysis. After three rounds of exploratory factor analysis, only two items remained in the second scale, which did not represent a suitable solution.

In the next round of the analysis, the one-factor solution was subjected to exploratory factor analysis. Only one item (number 18) did not meet with the requirement of a loading above 0,3 . The results are set out in Table 4 .

\section{TABLE 4}

EXPLORATORY FACTOR ANALYSIS - ONE-FACTOR SOLUTION

\begin{tabular}{llc}
\hline Item & \multicolumn{1}{c}{ Description } & $\begin{array}{c}\text { Factor } \\
\text { loading }\end{array}$ \\
\hline Q08 & Most of the time I have to force myself to go to work (R) & 0,811 \\
Q10 & $\begin{array}{l}\text { I feel that my job is no more interesting than others I } \\
\text { could get (R) }\end{array}$ & 0,749 \\
Q06 & I am often bored with my job (R) & 0,740 \\
Q14 & Each day of work seems like it will never end (R) & 0,681 \\
Q12 & I feel that I am happier in my work than most & 0,677 \\
Q05 & other people & 0,658 \\
Q07 & I enjoy my work more than my leisure time & 0,657 \\
Q16 & My job is pretty uninteresting (R) & 0,653 \\
Q11 & I definitely dislike my work (R) & 0,641 \\
Q15 & I like my job better than the average worker does & 0,563 \\
Q17 & I find real enjoyment in my work & 0,553 \\
Q04 & I consider my job rather unpleasant (R) & 0,548 \\
Q02 & My job is usually interesting enough to keep me & 0,489 \\
& from getting bored & \\
Q03 & It seems that my friends are more interested in & 0,419 \\
Q09 & I I am satir jobs (R) & 0,394 \\
Q01 & My job is like a hobby to me & 0,374 \\
Q13 & Most days I am enthusiastic about my work & 0,328 \\
\hline
\end{tabular}

The one-factor solution explained $61,3 \%$ of the total variance. An interactive item analysis of the 17 items yielded an internal consistency of 0,919 (Cronbach alpha).

In order to see whether there was a good fit between the data and the model, the one factor solution was subjected to a Confirmatory Factor Analysis (CFA) using the SAS-Proc Calis programme. The indices of the CFA indicated a good fit between the model and the data. The results are set out in Table 5 .

TABLE 5

INDICES OF THE CONFIRMATORY FACTOR ANALYSIS ONE-FACTOR SOLUTION

\begin{tabular}{lr}
\hline Fit indices & \\
\hline Goodness of fit Index (GFI) & 0,9227 \\
GFI Adjusted for degrees of Freedom (AGFI) & 0,9006 \\
Root Mean Square Residual (RMR) & 0,0420 \\
Parsimonious GFI (Mulaik, 1989) & 0,8073 \\
Chi-Square & 466,6293 \\
Chi-Square DF & 119,0000 \\
Independence model Chi-Square & 4293,1000 \\
Independence model Chi-Square DF & 136,0000 \\
RMSEA Estimate & 0,0647 \\
Bentler's Comparative Fit Index & 0,9164 \\
Akaike's Information criterion & 228,6293 \\
Bentler and Bonnet's (1980) Non-normed index & 0,9044 \\
Bollen (1986) Normed Index Rh01 & 0,8758 \\
Bollen (1988) Non-normed Index Delta2 & 0,9167 \\
\hline
\end{tabular}

Next, the one factor solution of the Job Satisfaction Scale was investigated further. A procedure advocated by Bagozzi and Heatherton (1994) was used. It is based on the principle that the fit indicated by the indices yielded by the CFA can be an underestimation of the quality of the fit when the scales included in the analysis consist of several items or when large samples are used. Bagozzi and Heatherton (1994) suggest that an aggregation of the factor scores can be used to reduce this problem.

The items on the Job Satisfaction Scale were then aggregated and again subjected to a CFA. The indices obtained indicated a much better fit between the model and the data.

The results are set out in Table 6.

TABLE 6

INDICES OF THE CONFIRMATORY FACTOR ANALYSIS ONE-FACTOR SOLUTION

\begin{tabular}{lr}
\hline Fit indices & \\
\hline Goodness of fit Index (GFI) & 0,9836 \\
GFI Adjusted for degrees of Freedom (AGFI) & 0,9509 \\
Root Mean Square Residual (RMR) & 0,0199 \\
Parsimonious GFI (Mulaik, 1989) & 0,4918 \\
Chi-Square & 28,2088 \\
Chi-Square DF & 5,0000 \\
Independence model Chi-Square & 1811,2000 \\
Independence model Chi-Square DF & 10,0000 \\
RMSEA Estimate & 0,0813 \\
Bentler's Comparative Fit Index & 0,9871 \\
Akaike's Information criterion & 18,2088 \\
Bentler and Bonnet's (1980) Non-normed index & 0,9742 \\
Bollen (1986) Normed Index Rh01 & 0,9689 \\
Bollen (1988) Non-normed Index Delta2 & 0,9872 \\
\hline
\end{tabular}

Based on the results of the Principal Factor Analysis, the CFA and the satisfactory reliability coefficient (Cronbach alpha), it can be stated with confidence that the Job Satisfaction Scale of Brayfied and Rothe (1951) can be used for aircraft pilots in the South African context.

\section{Multiple comparisons}

A series of one-way analyses of variance (ANOVA's) was carried out to determine whether the pilots' job satisfaction levels (dependent variable) differed in terms of the main areas of operation, the nature of the pilots' tasks, the type of licence held and the pilots' levels of command (independent variables). For this purpose, the pilots were divided into different groups, as indicated in Table 7.

Main areas of operation

The results of the one-way analysis of variance (ANOVA) regarding areas of operation are set out in Table 8 , which illustrates that there is a statistically significant difference, $F(2,529)=20,103 ; p<0,001$, between the mean job satisfaction scores of pilots operating in different areas. This supports Hypothesis H1. 
TABLE 7

Classification of pilots for analysis of Variance (anova)

Group of pilots

$\mathbf{N}$

Main areas of operation

National airline pilots

General aviation pilots

Military

Nature of flying duty

Passenger transport

Commercial aviation*

Training and instruction

80

Private pilots and student pilots

Licence

Airline transport pilot licence (ATP)

Commercial pilot licence (CPL)

Private pilot licence (PPL)

Level of command

Captain multi-crew

First officer multi-crew

Single pilot in command

* The commercial aviation category refers to freight, agriculture, aerial survey and patrol, construction and flying for industrial purposes.

TABLE 8

ANOVA: Job SATISFACTION BY MAIN AREAS OF OPERATION

\begin{tabular}{lccccc}
\hline Areas of operation & $\begin{array}{c}\text { Sum of } \\
\text { squares }\end{array}$ & df & $\begin{array}{c}\text { Mean } \\
\text { square }\end{array}$ & F & p(F) \\
\hline Between groups & 2040,059 & 2 & 1020,029 & 20,103 & $<0,001$ * \\
Within groups & 26842,174 & 529 & 50,741 & & \\
Total & 28882,233 & 531 & & & \\
\hline
\end{tabular}

${ }^{*} \mathrm{p}<0,001$

TABLE 9

SCHEFFE'S POST HOC MULTIPLE COMPARISONS OF THE AREAS OF OPERATION IN RELATION TO JOB SATISFACTION

\begin{tabular}{llccc}
\hline $\begin{array}{l}\text { (I)Areas of } \\
\text { operation }\end{array}$ & $\begin{array}{l}\text { (J)Areas of } \\
\text { operation }\end{array}$ & $\begin{array}{c}\text { Mean } \\
\text { difference(I-J) }\end{array}$ & Std error & $\mathrm{p}$ \\
\hline Airline pilots & General aviation & 3,4069 & 0,8116 & $0,000^{*}$ \\
& Military & 4,3965 & 0,7131 & $0,000^{*}$ \\
General aviation & Airline pilots & $-3,4069$ & 0,8116 & $0,000^{*}$ \\
& Military & 0,9897 & 0,7092 & 0,457 \\
Military & Airline pilots & $-4,3965$ & 0,7131 & $0,000^{*}$ \\
& General aviation & $-0,9897$ & 0,7902 & 0,457 \\
\hline
\end{tabular}

${ }^{*} \mathrm{p}<0,001$

Scheffé's post hoc multiple comparison technique was used to determine the statistical difference between the groups. The results (reported in Table 9) indicate that pilots who fly for major airlines are clearly more satisfied $(p<0,001)$ than any of the other groups of pilots. The mean job satisfaction scores of pilots who fly for major airlines $(73,9947)$ are higher than those of pilots operating in general aviation $(70,5878)$ or in the military arena $(69,5981)$.

Nature of flying duty

The results for the one-way analysis of variance (ANOVA) and the post hoc Scheffé test for the nature of flying duty are set out in Tables 10 and 11 respectively.
TABLE 10

ANOVA: JOB SATISFACTION BY NATURE OF FLYING DUTY

\begin{tabular}{lccccc}
\hline Job satisfaction & $\begin{array}{c}\text { Sum of } \\
\text { Squares }\end{array}$ & df & $\begin{array}{c}\text { Mean } \\
\text { Square }\end{array}$ & F & p(F) \\
\hline Between groups & 1635,879 & 3 & 545,293 & 8,925 & $<0,001^{*}$ \\
Within groups & 41914,598 & 686 & 61,100 & & \\
Total & 43550,477 & 689 & & & \\
\hline
\end{tabular}

${ }^{*} \mathrm{p}<0,001$

TABLE 11

SCHEFFÉ'S POST HOC MULTIPLE COMPARISONS OF FLYING DUTY IN RELATION TO JOB SATISFACTION

\begin{tabular}{|c|c|c|c|c|}
\hline $\begin{array}{l}\text { (I) Nature of } \\
\text { flying duty }\end{array}$ & $\begin{array}{l}\text { (J) Nature of } \\
\text { flying duty }\end{array}$ & $\begin{array}{c}\text { Mean } \\
\text { difference } \\
(\mathrm{I}-\mathrm{J})\end{array}$ & $\begin{array}{l}\text { Std } \\
\text { error }\end{array}$ & $\mathrm{p}$ \\
\hline \multirow[t]{3}{*}{ Passenger transport } & $\begin{array}{l}\text { Commercial aviation } \\
\text { work }\end{array}$ & 3,3536 & 0,9958 & $0,010^{*}$ \\
\hline & $\begin{array}{l}\text { Training and } \\
\text { instruction }\end{array}$ & 3,5912 & 0,9693 & 0,004 * \\
\hline & $\begin{array}{l}\text { Private and student } \\
\text { pilots }\end{array}$ & 2,6236 & 0,7263 & $0,005^{*}$ \\
\hline \multirow[t]{3}{*}{ Commercial aviation } & Passenger transport & $-3,3536$ & 0,9958 & $0,010^{*}$ \\
\hline & $\begin{array}{l}\text { Training and } \\
\text { instruction }\end{array}$ & 0,2376 & 1,2646 & 0,998 \\
\hline & $\begin{array}{l}\text { Private and student } \\
\text { pilots }\end{array}$ & $-0,7300$ & 1,0896 & 0,930 \\
\hline \multirow[t]{3}{*}{ Training and instruction } & Passenger transport & $-3,5912$ & 0,9693 & 0,004 * \\
\hline & $\begin{array}{l}\text { Commercial aviation } \\
\text { work }\end{array}$ & $-0,2376$ & 1,2646 & 0,998 \\
\hline & $\begin{array}{l}\text { Private and student } \\
\text { pilots }\end{array}$ & $-0,9676$ & 1,0658 & 0,843 \\
\hline \multirow[t]{3}{*}{ Private and student pilots } & Passenger transport & $-2,6236$ & 0,7263 & $0,005^{*}$ \\
\hline & $\begin{array}{l}\text { Commercial aviation } \\
\text { work }\end{array}$ & 0,7300 & 1,0896 & 0,930 \\
\hline & $\begin{array}{l}\text { Training and } \\
\text { instruction }\end{array}$ & 0,9676 & 1,0653 & 0,843 \\
\hline
\end{tabular}

${ }^{*} \mathrm{p}<0,01$

The information in Table 10 supports Hypothesis H2, namely that there is a significant difference between the mean job satisfaction scores of pilot groups performing different flying duties. The overall $\mathrm{F}$-value is significant, $\mathrm{F}(3,686)=8,925$; $\mathrm{p}<0,001$. The results of Scheffé's post hoc multiple comparisons (Table 11) indicated that pilots involved in transporting passengers reported significantly $(\mathrm{p}<0,01)$ higher levels of job satisfaction than the other groups of aviators. However, the levels of job satisfaction of commercial aviators, instructors and private and student pilots did not differ significantly from each other. The mean job satisfaction scores of the pilots performing different flying duties are the following: passenger transport $=71,9076$; commercial aviation $=68,5541$; training and instruction $=68,3165$ and private and student pilots $=69,2840$.

\section{Type of licence}

The results of the one-way analysis of variance (ANOVA) and Scheffe's post hoc multiple comparisons with regard to type of licence are set out in Tables 12 and 13 respectively. 
TABLE 12

ANOVA: JOB SATISFACTION BY TYPE OF LICENCE

\begin{tabular}{lrrrcc}
\hline & $\begin{array}{c}\text { Sum of } \\
\text { squares }\end{array}$ & df & $\begin{array}{c}\text { Mean } \\
\text { square }\end{array}$ & F & p (F) \\
\hline Between groups & 1920,865 & 2 & 960,433 & 17,158 & $<0,001^{*}$ \\
Within groups & 36663,767 & 655 & 55,975 & & \\
Total & 38584,632 & 657 & & & \\
\hline
\end{tabular}

${ }^{*} \mathrm{p}<0,001$

TABLE 13

SCHEFF'́'S POST HOC MULTIPLE COMPARISONS OF TYPE OF LICENCE IN RELATION TO JOB SATISFACTION

\begin{tabular}{llccc}
\hline (l) Licence & (J) Licence & $\begin{array}{c}\text { Mean } \\
\text { difference } \\
\text { (1-J) }\end{array}$ & $\begin{array}{c}\text { Std } \\
\text { error }\end{array}$ & p \\
\hline Airline transport (ATP) & Commercial (CPL) & 2,3577 & 0,7169 & $0,005^{*}$ \\
& Private (PPL) & 4,0650 & 0,6986 & $0,000^{*}$ \\
Commercial (CPL) & Airline transport (ATP) & $-2,3577$ & 0,7169 & $0,005 *$ \\
& Private (PPL) & 1,7073 & 0,7345 & 0,068 \\
Private (PPL) & Commercial (CPL) & $-1,7073$ & 0,7345 & 0,068 \\
& Airline transport (ATP) & $-4,0650$ & 0,6986 & $0,000^{*}$ \\
& & & &
\end{tabular}

${ }^{*} \mathrm{p}<0,01$

The results of the ANOVA in respect of job satisfaction according to the type of licence held are shown in Table 12. The table clearly indicates that there is a statistically significant difference $F(2,655)=17,158 ; p<0,001$ between the three licence categories. The significant F-value supports Hypothesis H3. Scheffé's post hoc multiple comparisons indicated that there is a difference between pilots with each of the three types of licences $(p<0,001)$. Pilots with an airline transport pilot licence (ATP) are the most satisfied group $(72,8678)$, followed by pilots with a commercial licence $(70,5101)$. The group with a private pilots' licence have the lowest mean score $(68,8028)$.

\section{Level of command}

The results of the one-way analysis of variance (ANOVA) and the post hoc multiple comparisons with regard to the level of command held by a pilot are set out in Tables 14 and 15 .

TABLE 14

ANOVA: JOB SATISFACTION BY LEVEL OF COMMAND

\begin{tabular}{lrrrrr}
\hline & $\begin{array}{c}\text { Sum of } \\
\text { Squares }\end{array}$ & df & $\begin{array}{c}\text { Mean } \\
\text { square }\end{array}$ & F & p(F) \\
\hline Between groups & 1077,924 & 2 & 538,962 & 8,901 & $<0,001$ * \\
Within groups & 34271,344 & 566 & 60,550 & & \\
Total & 35349,269 & 568 & & & \\
\hline
\end{tabular}

${ }^{*} \mathrm{p}<0,001$

The ANOVA of Table 14 clearly indicates that the levels of command held by pilots affect the job satisfaction of pilots. This result supports Hypothesis H4. The overall F-value is significant $\mathrm{F}(2,566)=8,901 ; \mathrm{p}<0,001$. The post hoc multiple comparisons (Table 15) indicate that first officers and captains operating in a multi-crew environment are more satisfied $(\mathrm{p}<0,01)$ with their work than single pilots in command of smaller aircraft. The mean job satisfaction scores for the three positions were 72,6462 for First Officer, 71,3775 for Captains and 69,2468 for single pilots.
TABLE 15

SCHEFFÉ'S POST HOC MULTIPLE COMPARISONS OF LEVEL OF COMMAND IN RELATION TO JOB SATISFACTION

\begin{tabular}{llccc}
\hline (I) Position & (J) Position & $\begin{array}{c}\text { Mean } \\
\text { difference } \\
\text { (I-J) }\end{array}$ & $\begin{array}{c}\text { Std } \\
\text { error }\end{array}$ & p \\
\hline $\begin{array}{l}\text { Captain multi-crew } \\
\text { multi-crew }\end{array}$ & First officer & $-1,2687$ & 0,8733 & 0,349 \\
& Pilot in command & 2,1306 & 0,7446 & $0,017^{*}$ \\
& Captain multi-crew & 1,2687 & 0,8733 & 0,349 \\
$\begin{array}{l}\text { First officer } \\
\text { multi-crew }\end{array}$ & Pilot in command & 3,3993 & 0,8505 & $0,000^{*}$ \\
& Captain multi-crew & $-2,1306$ & 0,7446 & $0,017^{*}$ \\
Pilot in command & First officer multi-crew & $-3,3993$ & 0,8505 & $0,000^{*}$ \\
\hline
\end{tabular}

${ }^{*} \mathrm{p}<0,05$

\section{DISCUSSION}

Pilots have to face the challenges of continuous development of improved and more complicated technology and aircraft, large amounts of information and a steady growth in the amount of daily flying activities. It can safely be assumed that the job satisfaction levels of pilots are influenced by their trying to cope with these demands on a daily basis. A review of aviation publications since 1990 indicated that there was very little information on the relationship between pilot-related factors and job satisfaction.

The results of the first part of the analyses performed indicate that South African pilots experience a relatively high level of job satisfaction. Pilots love flying. The study also attempted to determine whether there are significant differences between various pilot groups in terms of their job satisfaction levels. The results of the ANOVAs indicated significant differences between job satisfaction levels of some of the groups studied. In terms of areas of flight operation, there was a significant difference between pilots flying for national airlines and other areas such as general aviation and military pilots. Scheffé's post hoc multiple comparisons indicated that there are differences between the airline pilots on the one hand and general aviation and military pilots on the other. In terms of flying duties, there was a significant difference between pilots involved in passenger transportation and pilots involved in commercial flying, training and flying for recreation. Further results obtained from the ANOVAs indicated a significant difference between pilots with ATP, CPL and PPL licences. Significant differences were found with regard to the mean job satisfaction scores of pilots operating in a multicrew environment versus pilots operating in a single command position.

From the above results it is clear that pilots involved in the area of passenger transportation and working for national airlines experience a higher level of job satisfaction. This is an important finding, seeing that these pilots have a greater responsibility with regard to human life. More structure and set rules and standard operating procedures (SOPs) apply in national airlines than for other commercial operators. One can also argue that the larger carriers offer a more "protected" environment for pilots, resulting in higher job satisfaction, although they work long and irregular shifts. Other reasons for the higher job satisfaction may be the possibility of interaction during flight, sharing responsibilities, more prestige and more promotion opportunities and better remuneration. Stone and Babcock (1988) have an interesting view on promotion and remuneration. According to them, many of the larger airlines pay higher salaries, but their pilots progress more slowly from 
first officer to captain. Although smaller airlines pay less, they are sometimes more attractive to pilots because faster promotion is possible. In the end, both types of airlines yield similar career earnings, but a pilot who is promoted faster would experience more career satisfaction.

Pilots who make a living out of commercial flying (freight transport, crop dusting, aerial survey, construction and so forth), experience less job satisfaction. This may be due to the nature of their work environment. They earn less, have less job security, work mainly on their own and operate in a less structured environment. Smaller companies often expect their pilots to exceed safety margins in order to meet budget deadlines. This practice is referred to as "pilot pushing", a situation where small operators force a pilot, by direct or indirect means, to compromise safe practices in order to complete flights (Stone \& Babcock, 1988). This may cause conflict and uncertainty, which can result in lower job satisfaction.

Military pilots score lower on job satisfaction levels than both airline or commercial pilots. This finding can possibly be explained by a lack of job security in the South African Air Force, budget constraints, and very little flying time. However, much more research in this regard is necessary.

The study has a number of limitations. Although steps were taken to ensure that the sample was representative of all licenced pilots, the sample was dominated by white male pilots, which reflects the current status of the industry. It should be noted that the results must be interpreted with care. Differences were found between the various groups of pilots but these differences were relatively small. Although the results indicate that South African pilots are satisfied with their jobs and this implies that job satisfaction must have a positive influence on their job performance, no real measures of performance are included in this study.

Although the current study sheds some light on the job satisfaction levels of South African pilots, much more research is required. Further studies should investigate other factors that may influence pilots' job performance to determine what pilot behaviour may lead to human error.

\section{REFERENCES}

Bagozzi, R.P. \& Heatherton, T.F. (1994). A general approach to representing multifaceted personality constructs: application to self-esteem. Structural Equation Modeling, 1, 35-67.

Besco, R.O. (1989). Analyzing knowledge deficiencies in pilot performance. Proceedings of the Fifth International Symposium in Aviation Psychology, Ohio State University, Columbus, 61-86.

Brayfield, A.H. \& Rothe, H.F. (1951). Employee attitudes and employee performance. Journal of Applied Psychology, 35, 307-311.

Brayfield, A.H., Wells, R.V. \& Strate, M.W. (1957). Interrelationships among measures of job satisfaction and general satisfaction. Journal of Applied Psychology, 41, 201-205.

Carson, K.D., Carson, P.P., Roe, C.W., Birkenmeyer, B.J. \& Phillips, J.S. (1999). Four commitment profiles and their relationships to empowerment, service recovery, and work attitudes. Public Personnel Management, 28 (1), 1-13.
Dismukes, R.K. (1994). Aviation Human Factors Research in U.S. Universities: Potential Contributions to National Needs. http.//ntl.bts.gov/docs/aviation.html, 1-28.

FAA (1990) The National Plan for Aviation Human Factors. Federal Aviation Administration, Washington D.C.

Fuller, R., Johnston, N. \& McDonald N. (1995). Aviation Psychology in practice. Avebury Technical. Ashgate Publishing Limited, Aldershot.

Hatcher, L. (1994). A step by step approach to using the SAS sytem for Factor Analysis and Structural Equation Modeling. Cary, NC: SAS Institute Inc.

Hawkins, F.H. (1993). Human Factors in Flight. Ashgate Publishing Co., Vermont.

Hayward, B.J. \& Lowe, A.R. (1996). Applied Aviation Psychology: Achievement, Change and Challenge. Ashgate Publishing Co., Vermont.

Hayward, B.J. \& Lowe, A.R. (2000). Aviation Resource Management. Vol. 1, Ashgate Publishing Co., Vermont.

Iverson, R.D. (1999). An event history analysis of employee turnover: The case of hospital employees in Australia. Human Resources Management Review, 9 (4), 397-418.

Johnston, N., Fuller, R. \& McDonald N. (1995). Aviation Psychology: Training and Selection. Avebury Aviation. Ashgate Publishing, Aldershot.

Khaleque, A. \& Rahman, M.A. (1987). Perceived importance of job facets and overall job satisfaction of industrial workers. Human Relations, 40 (7), 401-146.

Lowe, A.R. \& Hayward, B.J. (2000). Aviation Resource Management. Vol. 2, Ashgate Publishing Co., Vermont.

McDonald, N., Johnston, N. \& Fuller, R. (1995). Aplications of Psychology to the Aviation Systems. Avebury Technical. Ashgate Publishing, Aldershot.

Martin, T.N. (1979). A contextual model of employee turnover intentions. Academy of Management Journal, 22, 313-324.

O'Hare, D. \& Roscoe. S. (1994). Flightdeck Performance: The Human Factor. Iowa State University Press, Iowa.

Orlady, H.W. \& Orlady, L.M. (1999). Human Factors in Multi-Crew Flight Operations. Ashgate Publishing Co., Vermont.

O'Reilly, C.A. \& Caldwell, D.F. (1979). Informational influence as a determinant of perceived task characteristics and job satisfaction. Journal of Applied Psychology, 64, 157-165.

Orpen, C. (1978). Relationship between job satisfaction and job performance between among western and tribal black employees. Journal of Applied Psychology, 63, 263-265.

Oshagbemi, T. (1999). Overall job satisfaction: How good are single versus multiple-item measures? Journal of Managerial Psychology, 14 (5), 388-403.

Robie, C., Ryan, A., Schmieder, R.A., Parra, L.E. \& Smith, P.C. (1998). The relation between job level and job satisfaction. Group and Organizational Management, 23 (4), 470-495.

Stinson, J.E \& Johnson, T.W. (1977). Tasks, individual differences and job satisfaction. Industrial Relations, 16, 315-322.

Stone, E.F., Mowday, R.T. \& Porter, L.W. (1977). Higher-order need strengths as moderators of the job scope-job satisfaction relationship. Journal of Applied Psychology, 62, 466-471.

Stone, R.B. \& Babcok, G.L. (1988). Airline Pilots' Perspective. In Wiener, E.L. \& Nagel, D.C. Human Factors in Aviation. Academic Press: Toronto.

Tett, R.P. \& Meyer, J.P. (1993). Job satisfaction, organizational commitment, turnover intention and turnover. Path analyser based on meta-analytical findings. Personnel Psychology, 46, 259-293.

Wiener, E.L. \& Nagel, D.C. (1988). Human Factors in Aviation. Academic Press: Toronto. 